\title{
Religião e horizonte utópico em jovens de comunidades
}

Orientadora: Prof $^{a}$. Dr ${ }^{a}$. Tereza M. P. Cavalcanti

terezapc@puc-rio.br

Pesquisador: André Gustavo Dias Lycurgo

alycurgo@bol.com.br

Projeto de Pesquisa: Teologia Bíblica, Interdisciplinaridade e Contexto Social

Fonte: $\mathrm{CNPq}$

A pesquisa versou sobre a realidade de uma comunidade carente situada no município de São Gonçalo (RJ). O objeto material de estudo foi a Rede Funk Social, uma organização de jovens funkeiros fluminense, incluindo suas raízes religiosas (Blues, Gospel, Soul). Tomando como referencial teórico o significado do conceito "utopia" em Tomás More, a pesquisa visava identificar co-relações entre a atitude utópica dos jovens da Rede e a noção de Reino de Deus. 